\title{
Effects of hyperthyroidism on the sensitivity of glycolysis and glycogen synthesis to insulin in the soleus muscle of the rat
}

\author{
George D. DIMITRIADIS, ${ }^{*}$ Brendan LEIGHTON,* Ioannis G. VLACHONIKOLIS, $\dagger$ \\ Mark PARRY-BILLINGS, ${ }^{*}$ R. A. John CHALLISS, ${ }^{*} \ddagger$ Doreen WEST* and Eric A. NEWSHOLME*§ \\ *Department of Biochemistry, University of Oxford, South Parks Road, Oxford OX1 3QU, \\ and †Department of Biomathematics, University of Oxford, South Parks Road, Oxford OX1 3UB, U.K.
}

1. The effects of hyperthyroidism on the sensitivity and responsiveness of glycolysis and glycogen synthesis to insulin were investigated in the isolated incubated soleus muscle of the rat. 2. Hyperthyroidism, which was induced by administration of tri-iodothyronine $\left(\mathrm{T}_{3}\right)$ to rats for 2, 5 or 10 days, increased fasting plasma concentrations of glucose, insulin and free fatty acids. 3. Administration of $T_{3}$ for 2 or 5 days increased the rates of glycolysis at all insulin concentrations studied: this was due to increased rates of both glucose phosphorylation and glycogen breakdown, but there was no effect of $\mathrm{T}_{3}$ on the sensitivity of glycolysis to insulin. However, administration of $\mathrm{T}_{3}$ for 10 days increased the sensitivity of the rate of glycolysis to insulin. 4. The concentration of adenosine in the gastrocnemius muscles of the rats was not different from controls after 5 days, but it was markedly decreased after 10 days of $\mathrm{T}_{3}$ administration. If these changes are indicative of changes in the soleus muscle, the increased sensitivity of glycolysis to insulin found after 10 days' $T_{3}$ administration could be due to the decrease in the concentration of adenosine. 5. Administration of $T_{3}$ decreased the sensitivity of glycogen synthesis to insulin and the glycogen content of the soleus muscles. This may explain the decreased rates of non-oxidative glucose disposal found in spontaneous and experimental hyperthyroidism in man. 6 . The rates of glucose oxidation did not change after 2 days, but they were increased after 5 and 10 days of $\mathrm{T}_{3}$ administration.

\section{INTRODUCTION}

There is considerable evidence that insulin resistance is often seen in the hyperthyroid state: glucose tolerance is impaired in response to intravenous or oral glucose, and the fasting plasma insulin concentration is raised in spontaneous and experimental hyperthyroidism in man [1-8] and in hyperthyroid animals [9-11].

It is known that the sensitivity of hepatic glucose production to insulin is decreased in hyperthyroid patients and in experimental hyperthyroidism in man [7,12-14]. However, the effects of hyperthyroidism on the sensitivity of glucose utilization in skeletal muscle to insulin are unclear. The rates of glucose uptake by the forearm of patients with hyperthyroidism or of healthy subjects treated with tri-iodothyronine $\left(\mathrm{T}_{3}\right)$ were either normal [15] or increased [5]; and, by the euglycaemicclamp technique, it was shown that the rate of insulinstimulated glucose disposal was elevated in experimental hyperthyroidism [7,13]. However, experiments with indirect calorimetry in hyperthyroid patients or in experimental hyperthyroidism in man indicated a decreased rate of non-oxidative glucose disposal, but an increased rate of glucose oxidation $[7,16,17]$.

In view of the variability of these results, the present study was undertaken to study systematically the effect of hyperthyroidism on the sensitivity and responsiveness of glucose utilization and glycogen synthesis by muscle to insulin. This has been done with the stripped soleus muscle isolated from hyperthyroid rats. The soleus, because of its fibre-type composition, is an excellent muscle preparation for this purpose [18]. The muscle incubation in vitro provides a controlled environment in which to analyse specifically the effect of hyperthyroidism on the rates of glycolysis and glycogen synthesis at various concentrations of insulin. These experiments were performed after 2, 5 or 10 days of $\mathrm{T}_{3}$ administration to the rats. Since changes in the concentration of adenosine have been implicated in changes in sensitivity of glycolysis to insulin in muscle [19], the concentration of adenosine has been measured in the muscles of the rats after 5 and 10 days' treatment with $\mathrm{T}_{3}$.

\section{MATERIALS AND METHODS}

\section{Animals}

Male Wistar rats (160-180 g) were purchased from Harlane-Olac, Bicester, Oxon., U.K., and were kept in the Department's animal house for 7 days with access to food and water ad libitum. Experimental hyperthyroidism was induced in the rats by intraperitoneal injection of $\mathrm{T}_{3}(0.65 \mu \mathrm{g} / \mathrm{g}$ body wt.) on 2,5 and 10 consecutive days; animals were killed $24 \mathrm{~h}$ after the final injection. Rats were fasted for 12-14 $\mathrm{h}$ before each experiment, and they were killed by cervical dislocation.

\section{Chemicals and enzymes}

All chemicals, biochemicals and enzymes were obtained from sources given previously [20]. In addition, $\mathrm{T}_{3}$, Dowex-2 $\left(\mathrm{Cl}^{-}\right.$form; dry mesh $\left.200-400\right)$, ammonium formate, Aprotinin and amyloglucosidase were obtained from Sigma Chemical Co., Poole, Dorset, U.K. $D-\left[U-{ }^{14} C\right] G l u c o s e$ was obtained from DuPont, Stevenage,

Abbreviation used: $T_{3}$, tri-iodothyronine.

$\ddagger$ Present address: Department of Pharmacology, University of Leicester, Leicester LE2 7LX, U.K.

$\S$ To whom reprint requests should be addressed. 
Herts., U.K. Sagatal (pentobarbitone) was obtained from May and Baker, Dagenham, Essex, U.K.

\section{Incubation of muscles}

Soleus-muscle strips were prepared as previously described [20,21]. All muscle incubations were carried out in Krebs-Ringer bicarbonate buffer containing $5.5 \mathrm{~mm}$-glucose, $1.5 \%(\mathrm{w} / \mathrm{v})$ defatted bovine serum albumin [22], $0.5 \mu \mathrm{Ci}$ of $\mathrm{D}-\left[\mathrm{U}-{ }^{14} \mathrm{C}\right] \mathrm{glucose} / \mathrm{ml}$ and various concentrations of insulin (see the Results section).

\section{Metabolite and hormone determinations}

The concentration of lactate in the incubation medium was assayed enzymically [23]. The rates of incorporation of $\left[{ }^{14} \mathrm{C}\right]$ glucose into glycogen (glycogen synthesis) and $\mathrm{CO}_{2}$ were measured as previously described $[24,25]$. The rates of ${ }^{14} \mathrm{CO}_{2}$ production were calculated on the basis of the specific radioactivity of pyruvate: these rates were never greater than $15 \%$ of the rate of lactate formation under any of the incubation conditions investigated. For determination of glycogen content, the soleus muscles were digested for $1 \mathrm{~h}$ in $1 \mathrm{M}-\mathrm{KOH}$ at $70^{\circ} \mathrm{C}$. The digest was acidified with acetic acid to $\mathrm{pH} 4.8$, amyloglucosidase (in acetate buffer, $\mathrm{pH} 4.8$ ) was added and the samples were incubated at $40^{\circ} \mathrm{C}$ for $2 \mathrm{~h}$ to allow complete degradation of glycogen to glucose. The glucose concentration was measured enzymically $[26,27]$.

The rates of hexose phosphorylation were determined by using 2-deoxyglucose. A trace amount of 2-deoxy$\left[2,6-{ }^{3} \mathrm{H}\right]$ glucose was added to the incubation medium, which contained $5.5 \mathrm{~mm}$-glucose: the final specific radioactivity in the incubation medium was $0.5 \mu \mathrm{Ci} / \mathrm{ml}$ and the final concentration of 2-deoxyglucose was $0.011 \mu \mathrm{M}$. The muscles were incubated for $60 \mathrm{~min}$. After incubation, muscles were removed, blotted and freeze-clamped, and the frozen muscles were powdered and homogenized in $6 \%(\mathrm{w} / \mathrm{v}) \mathrm{HClO}_{4}$. Precipitated protein was removed by centrifugation $(1500 \mathrm{~g}$-min). The supernatant $(1 \mathrm{ml})$ was placed on a $1.5 \mathrm{ml}$ Dowex-2 (formate form) ion-exchange column to separate $\left[{ }^{3} \mathrm{H}\right]$ deoxyglucose 6-phosphate from $\left[{ }^{3} \mathrm{H}\right]$ deoxyglucose. The columns were washed first with $10 \mathrm{ml}$ of distilled water containing $5 \mathrm{~mm}$-D-glucose and then with $8 \mathrm{ml}$ of $0.5 \mathrm{M}$-formic acid. After the formic acid wash, the deoxyglucose 6-phosphate was eluted with $6 \mathrm{ml}$ of $0.3 \mathrm{M}$-ammonium formate/1 $\mathrm{M}$-formic acid [28]. The radioactivity in $1 \mathrm{ml}$ samples of each eluate was measured in a liquid-scintillation counter. The fluxes from glucose to hexose monophosphate $(G$, representing the sum of the rates of glucosyl units going into glycogen and through the glycolytic pathway) and from hexose monophosphates to glycogen $(B)$ were calculated from the rate of total lactate formation $(J),\left[{ }^{14} \mathrm{C}\right]$ lactate formation $(\lambda)$ and ${ }^{14} \mathrm{C}$ incorporation into glycogen $(\gamma)$ by using the formulae $G=[(J+B) / J] \lambda$ and $B=J(\gamma / \lambda)[29]$. For measurement of the rate of conversion of glucose into lactate, $\left[{ }^{14} \mathrm{C}\right]$ lactate was separated from other labelled compounds in the incubation medium by using Dowex-2 ion-exchange chromatography [28].

Concentrations of adenosine were measured in gastrocnemius muscles of the rats by h.p.l.c., as previously described [30].

For the determination of plasma concentrations of glucose [26], insulin ([31], with rat insulin standards) and non-esterified fatty acids [32] the rats were anaesthetized with $40 \mu \mathrm{g}$ of pentobarbitone/g body wt., and blood was taken from the iliac artery in a heparinized syringe.
Blood was immediately centrifuged and plasma was stored at $-20^{\circ} \mathrm{C}$ with 1000 i.u. of Aprotinin $/ \mathrm{ml}$ until assayed. Plasma concentrations of $T_{3}$ were measured with an Amerlex radioimmunoassay kit (The Radiochemical Centre, Amersham, Bucks., U.K.).

The results are presented as means \pm S.E.M. Statistical significance was tested by using Student's non-paired $t$ test, regression analysis in groups and analysis of co-variance [33].

\section{RESULTS}

The body weight of the treated rats compared with saline-injected controls was unchanged after 2 days $(167 \pm 2$ versus $170 \pm 2 \mathrm{~g})$, but it was decreased after 5 days $(163 \pm 2$ versus $182 \pm 2 \mathrm{~g} ; P<0.01)$ and 10 days of $\mathrm{T}_{3}$ administration $(170 \pm 2$ versus $216 \pm 2 \mathrm{~g} ; P<0.01)$. The plasma concentrations of insulin were significantly increased after 5 days, but not after 10 days, of $\mathrm{T}_{3}$ administration (Table 1). This decrease in insulin with chronic $T_{3}$ administration may be due to an enhanced rate of degradation of insulin [7,34].

\section{Rates of glycolysis and glucose phosphorylation}

The administration of $\mathrm{T}_{3}$ for 2,5 or 10 days increased the rates of lactate formation (glycolysis) at all insulin concentrations (Table 2). However, the concentration of insulin required to stimulate glycolysis half-maximally $\left(E_{50}\right)$ was not different from that of controls after 2 or 5 days of $\mathrm{T}_{3}$ administration, but it was lower (i.e. insulin sensitivity was increased) after 10 days of treatment (Table 3). The responsiveness of glycolysis to insulin was unchanged after 2 days, but was increased after 5 and 10 days of treatment (Table 3).

The rate of glucose phosphorylation was measured directly by monitoring the rate of accumulation of ${ }^{3} \mathrm{H}$ labelled 2-deoxyglucose 6-phosphate in the muscle, and it was also calculated from the rates of incorporation of $\left[{ }^{14} \mathrm{C}\right]$ glucose into glycogen and lactate (see the Materials and methods section) after 2 and 5 days of $T_{3}$ administration. The changes in the measured or calculated rates of glucose phosphorylation after 2 and 5 days treatment were identical with those described above for the rates of lactate formation (Tables 4 and 5). Comparison of the rates of lactate formation (Table 2) with those of glucose phosphorylation (Tables 4 and 5) demonstrates that hyperthyroidism, even after 2 days, results in a higher rate of lactate formation than of glucose phosphorylation. This suggests that $T_{3}$ administration leads to an increased rate of glycogenolysis at all insulin concentrations. The difference between rates of glucose phosphorylation and lactate formation was analysed more systematically by studying the extent of correlation between rates of glucose phosphorylation $(G)$ and rates of total lactate formation $(J)$. The slopes of the regression lines after 2 and 5 days of $T_{3}$ administration were almost identical with those of controls (Fig. 1). This indicates that, for a given increase in the rates of glucose phosphorylation, there was a proportional increase in the rate of lactate formation during stimulation by insulin. Therefore the source of glucose residues for insulin-stimulated rates of lactate formation in the hyperthyroid muscles is primarily glucose. However, the intercepts of the plots on the ordinate (i.e. extrapolation of the data to zero rates of glucose phosphorylation) were not the same: the intercepts were higher at 2 and 5 
Table 1. Effects of $T_{3}$ administration on the plasma concentrations of $T_{3}$, glucose, insulin and non-esterified fatty acids in the rat

Values are presented as means \pm S.E.M., with the numbers of separate animals given in parentheses. The statistical significance of the difference from controls is indicated by: ${ }^{\mathrm{a}} P<0.05,{ }^{\mathrm{b}} P<0.01$ and ${ }^{\mathrm{c}} P<0.001$.

\begin{tabular}{|c|c|c|c|c|}
\hline & \multicolumn{4}{|c|}{ Plasma concn. } \\
\hline & $\begin{array}{c}\mathrm{T}_{3} \\
\text { (ng/ml) }\end{array}$ & $\begin{array}{l}\text { Glucose } \\
\text { (mg/dl) }\end{array}$ & $\underset{(\mu \text {-units } / \mathrm{ml})}{\text { Insulin }}$ & $\begin{array}{l}\text { Non-esterified } \\
\text { fatty acids } \\
\text { (mM) }\end{array}$ \\
\hline $\begin{array}{l}\text { Controls } \\
2 \text { Days } \mathrm{T}_{3} \\
5{\text { Days } \mathrm{T}_{3}}_{10 \text { Days } \mathrm{T}_{3}}\end{array}$ & $\begin{array}{l}0.51 \pm 0.03(5) \\
6.57 \pm 0.71(4)^{\mathrm{c}} \\
7.59 \pm 0.47(5)^{\mathrm{c}} \\
7.48 \pm 0.43(5)^{\mathrm{c}}\end{array}$ & $\begin{array}{c}94 \pm 3(8) \\
137 \pm 7(4)^{\mathrm{b}} \\
123 \pm 6(15)^{\mathrm{b}} \\
117 \pm 10(5)^{\mathrm{a}}\end{array}$ & $\begin{array}{c}17.8 \pm 3.4(9) \\
- \\
30.7 \pm 4.8(13)^{\mathrm{a}} \\
15.8 \pm 2.4(5)\end{array}$ & $\begin{array}{c}0.159 \pm 0.031(10) \\
- \\
0.322 \pm 0.037(11)^{\mathrm{b}} \\
0.303 \pm 0.041(5)^{\mathrm{a}}\end{array}$ \\
\hline
\end{tabular}

Table 2. Effects of $T_{3}$ administration to rats for 2,5 or 10 days on the rates of lactate formation, glycogen synthesis and glucose oxidation in the stripped soleus muscle at various insulin concentrations

Values are presented as means \pm S.E.M., with the numbers of separate incubations shown in parentheses. The statistical significance of the difference from controls is indicated by: ${ }^{\mathrm{a}} P<0.05,{ }^{\mathrm{b}} P<0.01$ and ${ }^{\mathrm{c}} P<0.001$.

\begin{tabular}{|c|c|c|c|c|c|}
\hline Rate measured & $\begin{array}{c}\text { Insulin } \\
(\mu \text {-units } / \mathrm{ml})\end{array}$ & Controls & 2 Days $T_{3}$ & 5 Days $T_{3}$ & 10 Days $T_{3}$ \\
\hline $\begin{array}{l}\text { Lactate formation } \\
(\mu \mathrm{mol} / \mathrm{h} \text { per } \mathrm{g})\end{array}$ & $\begin{array}{l}1 \\
10 \\
100 \\
1000 \\
10000\end{array}$ & $\begin{array}{r}8.9 \pm 0.3(23) \\
10.1 \pm 0.3(26) \\
12.4 \pm 0.3(33) \\
14.5 \pm 0.4(27) \\
14.4 \pm 0.4(26)\end{array}$ & $\begin{array}{l}13.2 \pm 0.7(6)^{\mathrm{c}} \\
12.9 \pm 0.7(6)^{\mathrm{c}} \\
15.3 \pm 0.7(6)^{\mathrm{c}} \\
16.8 \pm 1.2(6)^{\mathrm{a}} \\
17.9 \pm 1.6(6)^{\mathrm{a}}\end{array}$ & $\begin{array}{l}18.9 \pm 0.8(16)^{\mathrm{c}} \\
21.6 \pm 0.7(18)^{\mathrm{c}} \\
24.8 \pm 0.9(20)^{\mathrm{c}} \\
27.4 \pm 0.9(19)^{\mathrm{c}} \\
28.3 \pm 1.3(17)^{\mathrm{c}}\end{array}$ & $\begin{array}{l}24.9 \pm 2.6(10)^{\mathrm{c}} \\
26.3 \pm 2.1(10)^{\mathrm{c}} \\
33.7 \pm 0.8(8)^{\mathrm{c}} \\
34.8 \pm 0.8(5)^{\mathrm{c}} \\
35.3 \pm 2.4(5)^{\mathrm{c}}\end{array}$ \\
\hline $\begin{array}{l}\text { Glycogen formation } \\
(\mu \mathrm{mol} \text { of glucosyl } \\
\text { units/h per } \mathrm{g})\end{array}$ & $\begin{array}{l}1 \\
10 \\
100 \\
1000 \\
10000\end{array}$ & $\begin{array}{l}2.22 \pm 0.1(20) \\
2.83 \pm 0.2(20) \\
4.20 \pm 0.2(32) \\
6.14 \pm 0.2(20) \\
6.24 \pm 0.3(20)\end{array}$ & $\begin{array}{l}2.04 \pm 0.2(8) \\
1.85 \pm 0.1(7)^{\mathrm{c}} \\
2.93 \pm 0.4(8)^{\mathrm{b}} \\
4.30 \pm 0.4(8)^{\mathrm{c}} \\
5.44 \pm 0.5(5)\end{array}$ & $\begin{array}{l}2.16 \pm 0.4(8) \\
2.28 \pm 0.3(8) \\
2.56 \pm 0.2(22)^{\mathrm{c}} \\
4.91 \pm 0.3(8)^{\mathrm{b}} \\
5.65 \pm 0.4(8)\end{array}$ & $\begin{array}{l}1.93 \pm 0.3(5) \\
2.12 \pm 0.4(5) \\
3.01 \pm 0.3(5)^{\mathrm{b}} \\
4.45 \pm 0.5(5)^{\mathrm{c}} \\
4.30 \pm 0.1(5)^{\mathrm{c}}\end{array}$ \\
\hline $\begin{array}{l}\text { Glucose oxidation } \\
(\mu \mathrm{mol} / \mathrm{h} \text { per } \mathrm{g})\end{array}$ & $\begin{array}{l}1 \\
10 \\
100 \\
1000 \\
10000\end{array}$ & $\begin{array}{l}0.67 \pm 0.04(20 \\
0.76 \pm 0.02(18) \\
0.93 \pm 0.07(19) \\
1.04 \pm 0.04(18) \\
1.09 \pm 0.05(16)\end{array}$ & $\begin{array}{l}0.73 \pm 0.05(6) \\
0.73 \pm 0.08(6) \\
0.88 \pm 0.06(6) \\
0.92 \pm 0.09(6) \\
1.07 \pm 0.07(6)\end{array}$ & $\begin{array}{l}0.93 \pm 0.08(7)^{\mathrm{c}} \\
1.12 \pm 0.07(7)^{\mathrm{c}} \\
1.23 \pm 0.08(8)^{\mathrm{c}} \\
1.29 \pm 0.10(7)^{\mathrm{b}} \\
1.40 \pm 0.08(7)^{\mathrm{c}}\end{array}$ & $\begin{array}{l}3.65 \pm 0.43(5)^{\mathrm{c}} \\
3.67 \pm 0.06(5)^{\mathrm{c}} \\
3.57 \pm 0.01(5)^{\mathrm{c}} \\
4.01 \pm 0.35(5)^{\mathrm{c}} \\
4.61 \pm 0.34(5)^{\mathrm{c}}\end{array}$ \\
\hline
\end{tabular}

Table 3. Effects of $T_{3}$ administration on the sensitivity and responsiveness of glycolysis and glycogen synthesis to insulin in the soleus muscle of the rat

Values are presented as means \pm S.E.M., with the numbers of separate experiments shown in parentheses. The statistical significance of the difference from controls is indicated by: ${ }^{a} P<0.05$ and ${ }^{b} P<0.01$. Sensitivity is defined as the concentration of insulin required to stimulate the processes half-maximally. Responsiveness is defined as the rate of the process at maximal minus that at basal concentrations of insulin.

\begin{tabular}{|c|c|c|c|c|}
\hline & \multirow{2}{*}{\multicolumn{2}{|c|}{ Sensitivity $\left(E_{50}\right)$}} & \multicolumn{2}{|c|}{ Responsiveness (max. - basal) } \\
\hline & & & & Glvcogen \\
\hline & $\begin{array}{c}\text { Lactate } \\
\text { formation } \\
(\mu \text {-units } / \mathrm{ml})\end{array}$ & $\begin{array}{c}\text { Glycogen } \\
\text { synthesis } \\
(\mu \text {-units } / \mathrm{ml})\end{array}$ & $\begin{array}{c}\text { Lactate } \\
\text { formation } \\
(\mu \mathrm{mol} / \mathrm{h} \text { per } \mathrm{g})\end{array}$ & $\begin{array}{c}\text { synthesis } \\
\text { ( } \mu \text { mol of glucosyl } \\
\text { units/h per } \mathrm{g} \text { ) }\end{array}$ \\
\hline $\begin{array}{l}\text { Controls } \\
2 \text { Days } T_{3} \\
5 \text { Days } T_{3} \\
10 \text { Days } T_{3}\end{array}$ & $\begin{array}{c}92 \pm 18(18) \\
106 \pm 37(5) \\
98 \pm 16(11) \\
30.7 \pm 75)^{b}\end{array}$ & $\begin{array}{l}100 \pm 13(21) \\
405 \pm 140(5)^{\mathrm{a}} \\
497 \pm 100(11)^{\mathrm{b}} \\
-\end{array}$ & $\begin{array}{l}6.28 \pm 0.38(24) \\
6.03 \pm 1.13(6) \\
10.0 \pm 0.95(19)^{b} \\
10.7 \pm 0.55(5)^{b}\end{array}$ & $\begin{array}{l}4.70 \pm 0.18(29) \\
4.14 \pm 0.25(5) \\
4.52 \pm 0.30(15) \\
3.09 \pm 0.25(5)^{\mathrm{a}}\end{array}$ \\
\hline
\end{tabular}


Table 4. Effects of $T_{3}$ administration to rats for 2 or 5 days on the fluxes of glucose to hexose monophosphate ( $G$ ) and hexose monophosphate to glycogen $(B)$ in stripped soleus muscle of the rat at various insulin concentrations

Values (in $\mu \mathrm{mol}$ of glucosyl units/h per $\mathrm{g}$ ) are presented as means \pm S.E.M., with the numbers of separate incubations shown in parentheses. The statistical significance of the differences from controls is indicated by: ${ }^{\mathrm{b}} P<0.01$ and ${ }^{\mathrm{c}} P<0.001$.

\begin{tabular}{ccccc}
\hline Flux & $\begin{array}{c}\text { Insulin } \\
(\mu \text {-units/ml) }\end{array}$ & Controls & 2 Days $\mathrm{T}_{3}$ & 5 Days T \\
\hline \multirow{3}{*}{$G$} & 1 & $5.92 \pm 0.39(15)$ & $7.59 \pm 0.28(16)^{\mathrm{c}}$ & $7.18 \pm 0.25(6)^{\mathrm{c}}$ \\
& 10 & $6.13 \pm 0.38(11)$ & $7.80 \pm 0.60(6)^{\mathrm{b}}$ & $8.18 \pm 0.52(6)^{\mathrm{b}}$ \\
& 100 & $8.98 \pm 0.25(20)$ & $10.44 \pm 0.59(6)^{\mathrm{b}}$ & $10.60 \pm 0.54(8)^{\mathrm{b}}$ \\
& 1000 & $11.18 \pm 0.35(15)$ & $13.00 \pm 0.36(6)^{\mathrm{c}}$ & $15.26 \pm 1.63(8)^{\mathrm{b}}$ \\
& 10000 & $11.47 \pm 0.37(12)$ & $13.10 \pm 0.32(6)^{\mathrm{b}}$ & $15.25 \pm 0.85(8)^{\mathrm{b}}$ \\
& 1 & $3.01 \pm 0.30(15)$ & $2.41 \pm 0.39(6)$ & $2.44 \pm 0.42(5)$ \\
& 10 & $3.54 \pm 0.40(16)$ & $1.85 \pm 0.12(6)^{\mathrm{c}}$ & $2.67 \pm 0.22(5)$ \\
& 100 & $6.17 \pm 0.58(17)$ & $3.26 \pm 0.37(6)^{\mathrm{c}}$ & $4.59 \pm 0.17(5)^{\mathrm{b}}$ \\
& 1000 & $8.30 \pm 0.54(16)$ & $5.10 \pm 0.40(6)^{\mathrm{c}}$ & $5.99 \pm 0.82(5)^{\mathrm{b}}$ \\
& 10000 & $7.93 \pm 0.69(13)$ & $6.22 \pm 0.43(5)$ & $7.47 \pm 0.67(5)$
\end{tabular}

Table 5. Effects of $T_{3}$ administration to rats for 5 days on the rates of phosphorylation of ${ }^{3} \mathbf{H}$-labelled 2-deoxyglucose in the stripped soleus muscle at various insulin concentrations

Values are presented as means \pm S.E.M., with the numbers of separate incubations shown in parentheses. The statistical significance of the difference from controls is indicated by: ${ }^{\mathrm{a}} P<0.05,{ }^{\mathrm{b}} P<0.01$ and ${ }^{\mathrm{c}} P<0.001$.

\begin{tabular}{lll}
\hline & \multicolumn{2}{c}{$\begin{array}{c}\left.\text { Rate of 2-deoxy-D-[ }{ }^{3} \mathrm{H}\right] \text { glucose } \\
\text { phosphorylation (d.p.m.) }\end{array}$} \\
\cline { 2 - 3 } $\begin{array}{c}\text { Insulin } \\
(\mu \text {-units/ml) }\end{array}$ & \multicolumn{1}{c}{ Controls } & 5 Days $\mathrm{T}_{3}$ \\
\hline & & \\
1 & $191 \pm 7(7)$ & $234 \pm 19(8)^{\mathrm{a}}$ \\
10 & $199 \pm 11(7)$ & $245 \pm 17(8)^{\mathrm{a}}$ \\
100 & $260 \pm 20(7)$ & $332 \pm 16(8)^{\mathrm{a}}$ \\
1000 & $288 \pm 21(8)$ & $419 \pm 30(6)^{\mathrm{b}}$ \\
10000 & $305 \pm 8(7)$ & $421 \pm 15(5)^{\mathrm{c}}$ \\
\hline
\end{tabular}

days (Fig. 1). This supports the suggestion made above that hyperthyroidism leads to an insulin-independent increase in the rate of glycogenolysis. This was greater after 5 days than after 2 days' treatment.

The concentration of adenosine in the gastrocnemius muscle of the hyperthyroid rats was not different from that of controls after 5 days' $T_{3}$ administration, but it was markedly decreased after 10 days' $T_{3}$ administration (Table 6): it is after this period of time that an increase in the sensitivity of glycolysis to insulin is observed.

\section{Rates of glycogen synthesis}

Administration of $\mathrm{T}_{3}$ for 2 or 5 days had no effect on the rates of glycogen formation at basal or maximal insulin concentrations, but decreased these rates at submaximal insulin concentrations (Tables 2 and 3). This indicates a decrease in the sensitivity of glycogen synthesis to insulin in muscles from hyperthyroid animals. After 10 days of treatment, there was a decrease in the rates of glycogen formation at maximal as well as submaximal concentrations of insulin (Table 2). The rates of glycogen formation were also calculated from the rates of tatal

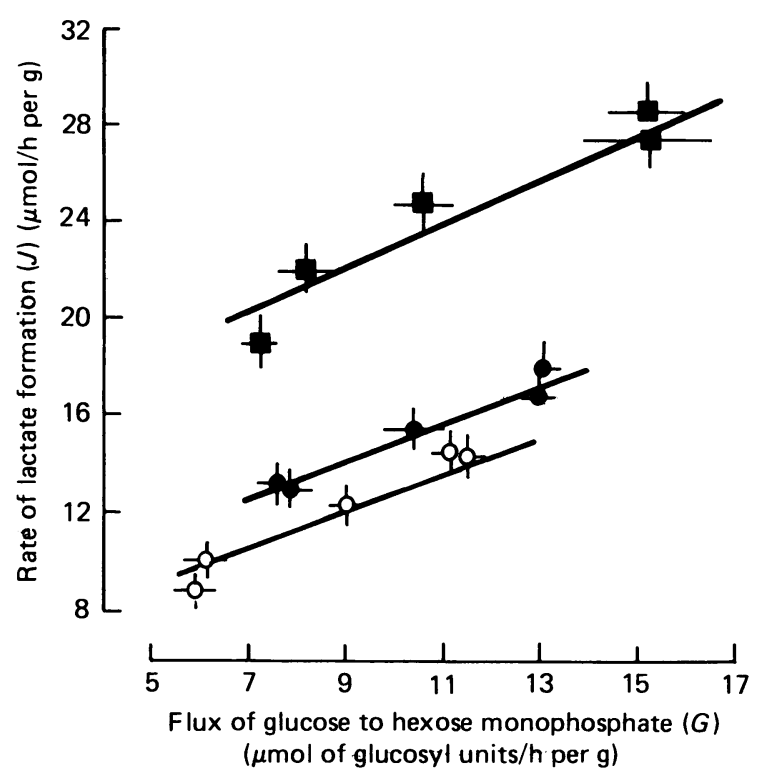

Fig. 1. Correlation between flux of glucose to hexose monophosphate $(G)$ and rate of lactate formation $(J)$ in the stripped soleus muscle of the rats after $T_{3}$ administration for 2 and 5 days

Values are presented as means \pm S.E.M. The slopes of the regression lines are $0.337 \pm 0.037,0.349 \pm 0.076$ and $0.436 \pm 0.054$ (common slope $0.365 \pm 0.028$ ), and the intercepts are $5.454 \pm 0.548$ in control muscles, $7.534 \pm 0.738$ after 2 days $(P<0.01$ versus control $)$ and $13.704 \pm 0.708$ after 4 days of $\mathrm{T}_{3}$ administration $(P<0.001$ versus controls). Symbols: $O$, controls; $O, 2$ days $T_{3} ; \square$, 5 days $T_{3}$.

lactate formation and $\left[{ }^{14} \mathrm{C}\right]$ glucose conversion into $\left[{ }^{14} \mathrm{C}\right]$ lactate (see the Materials and methods section) and gave changes qualitatively similar to those described above (Table 4).

The glycogen content of the soleus muscles after administration of $\mathrm{T}_{3}$ for 2 days $(5.76 \pm 0.24 \mathrm{mg} / \mathrm{g})$ was similar to that in controls $(6.26 \pm 0.21 \mathrm{mg} / \mathrm{g})$, but, as expected from the above results, it was decreased after 
Table 6. Effect of $T_{3}$ administration to rats for 5 and 10 days on the concentration of adenosine in the gastrocnemius muscle

Values are presented as means \pm S.E.M., with the numbers of separate animals given in parentheses. The statistical significance of the difference from controls (non-paired Student's $t$ test) is indicated by ${ }^{\mathrm{c}} P<0.001$. Values after 10 days' $T_{3}$ administration were all lower than the detection limit of the assay.

\begin{tabular}{lc}
\hline $\begin{array}{c}\text { Period of } \mathrm{T}_{3} \\
\text { administration } \\
\text { (days) }\end{array}$ & $\begin{array}{c}\text { Adenosine concn. } \\
\text { (nmol/g) }\end{array}$ \\
\hline 0 (controls) & $19.60 \pm 2.66(13)$ \\
5 & $25.07 \pm 3.17(6)$ \\
10 & $1.10 \pm 11(5)^{\mathrm{c}}$
\end{tabular}

$5(4.59 \pm 0.24 \mathrm{mg} / \mathrm{g} ; \quad P<0.001)$ and 10 days of $\mathrm{T}_{3}$ administration $(3.76 \pm 0.21 \mathrm{mg} / \mathrm{g} ; P<0.001)$.

\section{Rates of glucose oxidation}

The rates of glucose oxidation were similar to control values after administration of $\mathrm{T}_{3}$ for 2 days, but they were increased at all insulin concentrations after 5 days, and particularly after 10 days, of administration (Table 2). A plot of the regression line for glucose phosphorylation $(G)$ against that for the rates of glucose oxidation at the various insulin concentrations, in a way similar to that described in Fig. 1, showed a decrease in slope after 5 days of $T_{3}$ administration. However, the differences from controls did not reach statistical significance (results not shown).

\section{DISCUSSION}

Administration of $T_{3}$ to the rats decreased the rates of glycogen synthesis to insulin in the isolated incubated soleus muscle (Table 2) and decreased glycogen content, confirming previous reports in skeletal muscle of hyperthyroid man [35] and rats [36]. These results suggest that the decreased rates of non-oxidative glucose disposal observed in spontaneous and experimental hyperthyroidism in man $[7,16]$ are due to decreased sensitivity of glycogen synthesis to insulin.

Hyperthyroidism increased the rates of glycolysis in the isolated incubated soleus muscle. The results presented in Tables 2 and 4 and in Fig. 1 demonstrate that this was due to two effects: increased rates of glucose phosphorylation and increased rates of glycogenolysis. This effect might be explained by a direct action of $T_{3}$ or by increased sensitivity of the soleus muscles from hyperthyroid rats to endogenous catecholamines [37,38]. In order to distinguish between these two possibilities, further experiments should be carried out with $\beta$ adrenoceptor agonists or antagonists.

The increased rates of glucose phosphorylation observed at all insulin concentrations after 2 or 5 days' $\mathrm{T}_{3}$ treatment are probably due to an increased number of glucose transporters in the membrane, and hence an increase in the intracellular glucose concentration (see [39]). This explanation assumes that the rate of glucose transport is limiting for the process of glucose phosphoryl- ation $[39,40]$. To account for the increased maximal response of glucose phosphorylation to insulin, the number of transporters in the intracellular store should also be increased. After 10 days of $T_{3}$ treatment the sensitivity of glycolysis to insulin is increased (Tables 2 and 3). It is suggested that this is due to an effect of $T_{3}$ on the sensitivity to insulin of the process that controls the number or activity of the glucose transporters.

The effects of $T_{3}$ on the sensitivity and responsiveness to insulin of glucose uptake are most probably mediated through post-receptor mechanisms [7,41,42]. Although insulin-receptor binding was not measured in the present study, the latter view is supported by increased rates of glycolysis but decreased rates of glycogen synthesis in the soleus muscles (Table 2).

Previous studies from our laboratory have demonstrated that a decrease in the concentration of adenosine in the muscle markedly increases the sensitivity of glycolysis, but not glycogen synthesis, to insulin $[19,40]$. The concentration of adenosine in the gastrocnemius muscles of the rats, from which soleus muscle was removed, was unchanged after 5 days, but it was markedly decreased after 10 days of $T_{3}$ administration (Table 6). If changes in adenosine concentration in gastrocnemius muscle are indicative of changes in concentration in the soleus, this finding supports the suggestion that administration of $T_{3}$ for 10 days results in increased sensitivity of glycolysis to insulin via a decrease in the concentration of adenosine in muscle. Such a mechanism for this increase in sensitivity of glycolysis to insulin is consistent with the findings of no change in sensitivity and no change in adenosine concentration after 5 days' $T_{3}$ administration and no similar change in sensitivity of glycogen synthesis to insulin.

The rates of glucose oxidation were identical with those of controls after 2 days of hyperthyroidism, but increased at each insulin concentration after 5 and particularly after 10 days of hyperthyroidism (Table 2). The most likely explanation for this is a marked increase in the activity of pyruvate dehydrogenase, which has recently been suggested to be rate-determining for glucose oxidation under conditions of insulin infusion [43]. However, the slope of the regression line of insulinstimulated rates of glucose phosphorylation against rates of glucose oxidation was lower in the hyperthyroid muscles compared with controls: this suggests that, although there is an insulin-independent increase in glucose oxidation (i.e. glucose oxidation at 1 or $10 \mu$ units of insulin $/ \mathrm{ml}$ ), there may be a defect in the activation of this process by insulin in hyperthyroidism.

The data in the present paper suggest that hyperthyroidism will result in increased rates of glycolysis in muscle in vivo. And, since after 10 days' treatment the sensitivity of glycolysis to insulin is increased, the resistance to insulin observed in vivo $\{[7,12-14]$ and elevated fasting plasma glucose and insulin concentrations in the hyperthyroid rats in the present study (Table 1)\} cannot be explained by effects of hyperthyroidism on muscle. Furthermore, the elevation of plasma concentrations of non-esterified fatty acids in the presence of increased glucose uptake in muscle in vivo in hyperthyroidism $[5,7]$ indicates that the glucose/fatty acid cycle cannot be responsible for the insulin resistance observed in this condition. The resistance may be due to a decreased sensitivity of hepatic gluconeogenesis to 
insulin $[9,44-46]$, resulting in increased glucose production by the liver [7].

Increased rates of glycolysis in skeletal muscle in hyperthyroidism will lead to increased plasma concentrations of lactate [5,7], increasing Cori-cycle activity [47]. Increased Cori-cycle activity would consume a considerable amount of energy, since the resynthesis of glucose in the liver requires the expenditure of more ATP than is obtained from glycolysis in muscle (see [39]). This could explain, at least in part, the thermogenic effect of $\mathrm{T}_{3}$. Increased sensitivity of tissues to catecholamines as a result of elevated concentrations of $T_{3}[37,38]$ would also be expected to increase the rate of substrate cycling $[48,49]$, and this will also result in a thermogenic effect.

We acknowledge the financial support from the British Diabetic Association and Medical Research Council. G.D.D. was a Fellow of the British Council. We are grateful to Ms. Jane Bond for superb technical assistance, and to Ms. Melanie Burnett and Ms. Pauline Darling, from Diabetes Research Laboratory in Radcliffe Infirmary, for kindly performing the insulin radioimmunoassay.

\section{REFERENCES}

1. Lamberg, B. (1965) Acta Med. Scand. 174, 351-362

2. Doar, J., Stamp, T., Wynn, V. \& Audhya, T. (1969) Diabetes 18, 633-639

3. Anderson, O., Friis, T. \& Ollesen, B. (1977) Acta Endocrinol. (Copenhagen) 84, 576-587

4. Kabadi, U. \& Eisenstein, A. (1980) J. Clin. Endocrinol. Metab. 50, 392-396

5. Sandler, M., Robinson, R., Rabin, D., Lacy, W. \& Abumrad, N. (1983) J. Clin. Endocrinol. Metab 56, 479-485

6. Osei, K., Falko, J., O'Dorisio, T. \& Adam, D. (1984) Diabetes Care 7, 471-475

7. Dimitriadis, G., Baker, B., Marsh, H., Mandarino, L., Rizza, R., Bergman, R., Haymond, M. \& Gerich, J. (1985) Am. J. Physiol. 248, E593-E601

8. Shen, D. \& Davidson, M. (1985) J. Clin. Endocrinol. Metab. 60, 1038-1041

9. Okajima, F. \& Ui, M. (1979) Biochem. J. 182, 565-575

10. Muller, M. \& Seitz, H. (1980) Pflugers Arch. 386, 47-52

11. Muller, M., Paschen, U. \& Seitz, H. (1983) Endocrinology (Baltimore) 112, 2025-2031

12. Laville, M., Riou, J., Bougneres, P., Canivet, B., Beylot, M., Cohen, R., Serusclat, P., Dumontet, C., Berthezene, F. \& Mornex, R. (1984) J. Clin. Endocrinol. Metab. 58, 960-965

13. Bratush-Marrain, P., Gasic, S. \& Waldhausl, W. (1984) Am. J. Physiol. 247, E681-E687

14. Wennlund, A., Felig, Ph., Hagenfeldt, L. \& Wahren, J. (1986) J. Clin. Endocrinol. Metab. 65, 174-180

15. Butterfield, W. \& Whichelow, M. (1964) Metab. Clin. Exp. 13, 620-628

16. Randin, J., Scazziga, B., Jequier, E. \& Felber, J. (1985) J. Clin. Endocrinol. Metab. 61, 1165-1171

17. Randin, J., Tappy, L., Scazziga, B., Jequier, E. \& Felber, J. (1986) Diabetes 35, 178-181

18. Johnson, M. \& Turnbull, D. (1984) Q. J. Exp. Physiol. 69, 257-270
19. Challiss, R. A. J., Leighton, B., Lozeman, F. \& Newsholme, E. A. (1978) in Topics and Perspectives in Adenosine Research (Gerlach, E. Becker, B., eds.), pp. 276-285, Springer-Verlag, Berlin and Heidelberg

20. Espinal, J., Dohm, L. \& Newsholme, E. A. (1983) Biochem. J. 121, 453-458

21. Crettaz, M., Prentki, M., Zaninetti, D. \& Jeanrenaud, B. (1980) Biochem. J. 186, 525-534

22. Chen, R. (1967) J. Biol. Chem. 242, 173-181

23. Engel, P. \& Jones, J. (1978) Anal. Biochem. 88, 475-484

24. Cuendet, G., Loten, E., Jeanrenaud, B. \& Renold, A. (1976) J. Clin. Invest. 58, 1078-1088

25. Leighton, B., Budohoski, L., Lozeman, F., Challiss, R. A. J. \& Newsholme, E. A. (1985) Biochem. J. 227, 337-340

26. Bergmeyer, H., Bernt, E., Schmidt, F. \& Stork, H. (1974) in Methods of Enzymatic Analysis (Bergmeyer, H., ed.), pp. 1196-1201, Academic Press, New York and London

27. Keppler, D. \& Decker, K. (1974) in Methods of Enzymatic Analysis (Bergmeyer, H., ed.), pp. 1127-1131, Academic Press, New York and London

28. Hammerstedt, R. (1980) Anal. Biochem. 109, 443-448

29. Challiss, R. A. J., Crabtree, B. \& Newsholme, E. A. (1987) Eur. J. Biochem. 163, 205-210

30. Lozeman, F., Challiss, R. A. J., Leighton, B. \& Newsholme, E. A. (1987) Pflugers Arch. 410, 192-197

31. Albano, J., Ekins, R., Maritz, G. \& Turner, R. (1972) Acta Endocrinol. (Copenhagen) 70, 487-509

32. Laurel, S. \& Tibling, G. (1967) Clin. Chim. Acta 16, $57-60$

33. Armitage, P. \& Berry, G. (1987) Statistical Methods in Medical Research, 2nd edn., Blackwell, Oxford

34. Marecek, R. \& Feldman, J. (1973) Endocrinology (Baltimore) 92, 1604-1611

35. Celsing, F., Blomstrand, E., Melichna, J., Terrados, N., Clausen, N., Lins, P. \& Jansson, E. (1986) Clin. Physiol. 6, 171-181

36. Remesar, X. \& Alemany, M. (1982) Horm. Metab. Res. 14, 179-182

37. Williams, L. \& Lef kowitz, R. (1977) J. Biol. Chem. 252, 2787-2789

38. Ginsberg, A., Clutter, W., Shah, S. \& Cryer, Ph. (1981) J. Clin. Invest. 67, 1785-1791

39. Newsholme, E. A. \& Leech, A. (1983) Biochemistry for the Medical Sciences, John Wiley and Sons, New York and London

40. Leighton, B., Lozeman, F., Vlachonikolis, I. G., Challiss, R. A. J., Pitcher, J. \& Newsholme, E. A. (1988) Int. J. Biochem. 20, 23-27

41. Heise, E., Joost, H. \& Hasselblatt, A. (1982) Endocrinology (Baltimore) 110, 955-960

42. Arner, P., Bollinder, A., Wennlund, A. \& Ostman, J. (1984) Diabetes 33, 369-375

43. Mandarino, L., Wright, K., Verity, L., Nichols, J., Bell, J. M., Kolterman, O. \& Beck-Nielsen, H. (1987) J. Clin. Invest. 80, 655-663

44. Freedland, R. \& Krebs, H. (1967) Biochem. J. 104, 45-51

45. Muller, M. \& Seitz, J. (1980) Life Sci. 27, 827-835

46. Sestoft, L. (1980) Clin. Endocrinol. 13, 489-506

47. Huang, M. \& Lardy, H. (1981) Arch. Biochem. Biophys. 209, 41-51

48. Challiss, R. A. J., Arch, J. \& Newsholme, E. A. (1985) Biochem. J. 231, 217-220

49. Newsholme, E. A., Challiss, R. A. J., Leighton, B. Lozeman, F. \& Budohoski, L. (1987) Nutrition 3, 195-200 